\title{
Clinical trials of Ebola treatment to start in Africa
}

\author{
Anne Gulland
}

London

A $£ 3.2 \mathrm{~m}$ ( $€ 4.1 \mathrm{~m} ; \$ 5.2 \mathrm{~m}$ ) grant to fund clinical trials of drugs to treat Ebola virus disease in west Africa will not be a "magic bullet" in containing the outbreak, and good public health measures were still needed, experts have said.

The UK charity the Wellcome Trust has announced that it will fund a consortium that will begin trials of treatments in the affected countries of Sierra Leone, Liberia, and Guinea in November. The consortium includes researchers from Oxford University, the charity Médecins Sans Frontières, the World Health Organization, the Institut Pasteur, and the Institut Pasteur de Dakar.

Jeremy Farrar, director of the Wellcome Trust, told a press conference on 23 September that the two most promising treatments were plasma from convalescent patients and monoclonal antibodies such as the drug ZMapp. However, he said that if the trials were shown to be successful they would have a greater effect on future epidemics of Ebola virus than the current one.

"The control of this epidemic will be through classic methods of public health," he said. "There will be inevitable future epidemics and we must not be in a position again where we do not have available vaccines and therapeutics. We have to seize the opportunity of this terrible circumstance for the future."

A study by WHO and Imperial College London, published in the New England Journal of Medicine, has projected that the number of cases will rise "exponentially" to more than 20000 by the beginning of November, exceeding previous WHO estimates of 20000 cases in the outbreak as a whole. ${ }^{1}$ The study showed a total case fatality rate of $70.4 \%$, but the rate is lower among patients who have been hospitalised, showing that good hospital care reduces mortality. The fact that the outbreaks in Nigeria and Senegal, where healthcare systems are stronger, have been contained is evidence of this, the paper said.

Chris Whitty, chief scientific adviser and director of research and evidence at the UK Department for International Development, told the press conference that it was vital that the affected populations understood the importance of getting to hospital. "It's not the situation that if you get Ebola your cards are marked. We can improve outcomes with fluids and good supportive care," he said.

He added that the current method of contact tracing, whereby staff actively sought cases of the disease in the community, had to change, and that patients with symptoms should come to hospital. However, the infrastructure needed to support this, he said, and patients had to be confident that they would get better treatment at hospital than at home.

David Heymann, professor of infectious disease epidemiology at the London School of Hygiene and Tropical Medicine, told the press conference that African innovation was needed, citing this weekend's lockdown in Sierra Leone. He said that dead bodies were found and buried, and the government managed to get health messages to $72 \%$ of households.

"These were positive outcomes ... It went against much of the international advice, but maybe this was an innovation that will make the difference," he said.

The New England Journal of Medicine study showed that although the current outbreak was bigger than previous outbreaks, the clinical course of the infection and the transmissibility of the virus were similar to those in previous outbreaks. What made this one different was the dysfunctional healthcare systems of the three affected countries and the intermixing of the populations.

Peter Piot, director and professor of global health at the London School of Hygiene and Tropical Medicine, told reporters that another important factor was the slow international response. He said it was no longer an outbreak but a "humanitarian crisis."

"It took three months between the first case being reported and the disease being identified [and] took another five months and 1000 deaths before WHO declared this a public health emergency and before the world started getting serious," he said.

Sally Davies, chief medical officer for England, told the press conference that a request she sent out last Friday for NHS staff to volunteer in the affected countries had already garnered 164 responses. Staff would receive full training in infection control and would work in internationally run treatment centres, she said.

thebmj.com Editorial: Ebola in an unprepared Africa (BMJ 2014;349:g5597, doi:10.1136/bmj.g5597); Blog by Grazia Caleo: Ebola-a blind outbreak (http://blogs.bmj.com/bmj/2014/09/18/graziacaleo-ebola-a-blind-outbreak)

1 WHO Ebola Response Team. Ebola virus disease in west Africa: the first 9 months of the epidemic and forward projects. N Engl J Med 23 Sep 2014, doi:10.1056/NEJMoa1411100. 